\title{
Trace metal and radionuclide pollution in marine sediments of the Aegean Sea (Izmir Bay and Didim)
}

\author{
S. Aközcan · A. Uğur Görgün
}

Received: 21 June 2012/ Accepted: 19 October 2012/Published online: 2 November 2012

(C) The Author(s) 2012. This article is published with open access at Springerlink.com

\begin{abstract}
To determine radioactivity and trace metal levels, surface sediments were collected from two important areas (İzmir Bay and Didim) in the Aegean Sea region of Turkey, and were analyzed for concentrations of ${ }^{210} \mathrm{Po}$, ${ }^{210} \mathrm{~Pb}$ and trace metals (Cd, Cr, $\mathrm{Cu}, \mathrm{Fe}, \mathrm{Mn}, \mathrm{Ni}, \mathrm{Pb}$ and $\mathrm{Zn}$ ). The average ${ }^{210} \mathrm{Po}$ and ${ }^{210} \mathrm{~Pb}$ massic activities in sediments varied in the range of $24 \pm 5$ to $126 \pm 6 \mathrm{~Bq} \mathrm{~kg}^{-1}$ dry wt. and $18 \pm 3$ to $59 \pm 4 \mathrm{~Bq} \mathrm{~kg}^{-1}$ dry wt., respectively. Izmir Bay exhibited the highest polonium activities in sediments, likely due to specific sedimentation processes and other sediment characteristics. The trace metal results showed that the Izmir Bay is facing trace metal pollution. The metal concentrations in sediment samples are low compared to those from the other neighboring marine environments.
\end{abstract}

Keywords Sediment $\cdot$ Trace metal $\cdot{ }^{210} \mathrm{Po} \cdot{ }^{210} \mathrm{~Pb}$. Aegean Sea

\section{Introduction}

The importance of monitoring radionuclides and trace metals is related to the impact of these elements on the

\footnotetext{
S. Aközcan $(\square)$

Department of Physics, Campus of Kavakli,

Kirklareli University, Kavakli,

Kirklareli, Turkey

e-mail: sakozcan35@yahoo.com

A. Uğur Görgün

Institute of Nuclear Sciences, Ege University,

Izmir 35100, Turkey
}

marine environment. Several natural and artificial radionuclides have been used in environmental studies, especially in marine processes. ${ }^{210} \mathrm{Po}$ and ${ }^{210} \mathrm{~Pb}$ are important natural radionuclides used in studies on the marine environment.

${ }^{210} \mathrm{Po}\left(t_{1 / 2}=138\right.$ days $)$, a high-energy $\alpha$-particle emitter in the ${ }^{238} \mathrm{U}$ decay chain, is a naturally occuring radionuclide formed by the beta decay of its grandparent of ${ }^{210} \mathrm{~Pb}$ $\left(t_{1 / 2}=22.3\right.$ years $)$ via ${ }^{210} \mathrm{Bi}$. The main source of ${ }^{210} \mathrm{Po}$ and ${ }^{210} \mathrm{~Pb}$ is ${ }^{222} \mathrm{Rn}$ emanation from the continents. In the aquatic environment, ${ }^{210} \mathrm{Po}$ is largely produced from the decay of ${ }^{210} \mathrm{~Pb}$ deposited from the atmosphere (Stepnowski and Skwarzec 2000). The naturally occuring radionuclides ${ }^{210} \mathrm{Po}$ and ${ }^{210} \mathrm{~Pb}$ are important because of their contributions to the natural radiation dose and technologically enhanced releases from sources of natural radioactivity (Vreček et al. 2004).

Coastal environments are subjected to metal contamination via inputs from main natural sources (rock weathering, soil erosion, dissolution of water-soluble salts), industrial and urban sources (municipal wastewater-treatment plants, manufacturing industries, and agricultural activities etc.) that are transported via river discharge and eolians processes (Güven and Akınc1 2008; Uluturhan et al. 2011).

Major indicators of pollution in aquatic environments are contaminated sediments. Sediments are the primary repository of radionuclides and chemicals entering the marine environment (Saçan et al. 2010). Thus, marine sediments are commonly used as environmental matrices in chemical and radioactive monitoring programs.

This study presents ${ }^{210} \mathrm{Po},{ }^{210} \mathrm{~Pb}$ and trace metal levels that were measured in marine sediments from two points in the Aegean Sea coast (Izmir Bay and Didim). 
Fig. 1 The map of the study areas

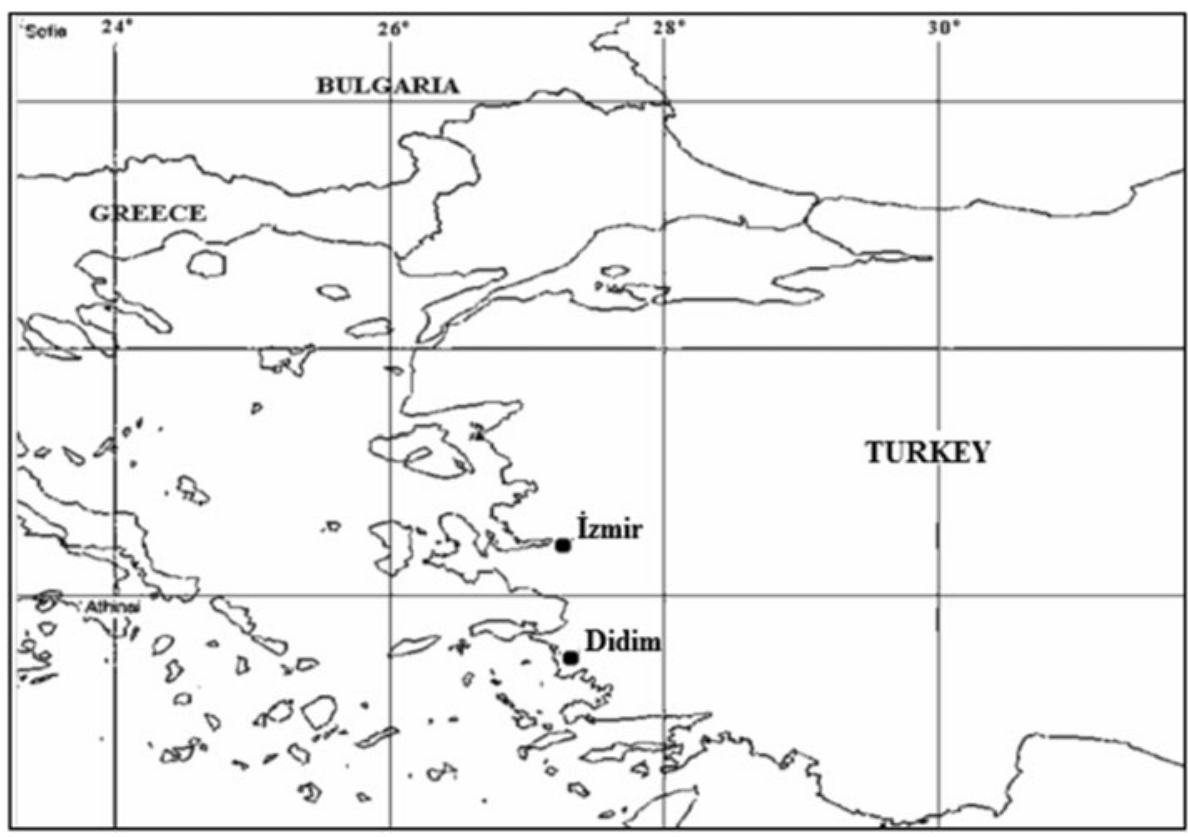

\section{Materials and methods}

Sample collection and preparation

Surface marine sediment samples were collected using van-veen grab for trace metals and radionuclides during 2006-2007 from two stations in the coast of Aegean Sea every month. The locations of sampling stations are given in Fig. 1.

${ }^{210} \mathrm{Po}$ and ${ }^{210} \mathrm{~Pb}$ measurements

The marine sediment samples were weighed and ovendried to a constant weight at $80{ }^{\circ} \mathrm{C}$ and then thoroughly mixed. The samples were ground and passed through a $2 \mathrm{~mm}$ mesh followed by homogenization.

After the addition of a standardized amount of ${ }^{209} \mathrm{Po}$ (4.88 MeV alpha emission, $t_{1 / 2}=109$ year) tracer, each sample was dissolved using three portions of concentrated $20 \mathrm{~mL} \mathrm{HNO}_{3}$ and evaporated to near dryness on a hot plate at $55{ }^{\circ} \mathrm{C}$. Then $2 \mathrm{~mL} \mathrm{H}_{2} \mathrm{O}_{2}$ was added, and evaporated to near dryness. The sample residuals were treated with three portions of $20 \mathrm{~mL} \mathrm{HCl}$, and evaporated to near dryness. Finally, the samples were dissolved in $200 \mathrm{~mL}$ of $0.5 \mathrm{M}$ $\mathrm{HCl}$, and ascorbic acid of $4 \mathrm{mg}$ was added to the plating solution to reduce iron. The temperature of the solution was kept constant at $70{ }^{\circ} \mathrm{C}$ while stirring, and a copper disk was introduced into the solution in such a way that only one side of the disk was available for plating. The polonium was spontaneously deposited onto the surface of the disk for $5 \mathrm{~h}$ at $70{ }^{\circ} \mathrm{C}$. The copper disk was then removed, washed with distilled water and dried at room temperature (Flynn 1968).
${ }^{210}$ Po levels were measured via $5.30 \mathrm{MeV}$ alpha particle emission rates using a high-resolution alpha spectrometer equipped with $450 \mathrm{~mm}^{2}$ Passivated Implanted Planar Silicon (PIPS) detector (Canberra Model 7401 Alpha PIPS dedector). The spectrometer was connected to a conventional personal computer (PC) using a network connection. The different parameter settings and the viewing of spectra were performed using the commercially available software (Genie-2000 Basic Spectroscopy Software). Contamination of detectors with polonium isotopes such as ${ }^{210} \mathrm{Po}$ and ${ }^{209} \mathrm{Po}$ probably occurs by some other process than alpha recoil. This is probably due to the inherent volatility of polonium at low pressure. Polonium activity is transferred from the sample sources to the detectors, a very serious problem with the long-lived Po-210 and even worse when working with Po-209 $\left(t_{1 / 2}=102 \mathrm{y}\right.$ ) as a yield tracer (Sill and Olsen 1970).

After the first deposition of ${ }^{210} \mathrm{Po}$, the residual $0.5 \mathrm{M}$ $\mathrm{HCl}$ was kept for 1 year to allow ${ }^{210} \mathrm{Po}$ in-growth from the ${ }^{210} \mathrm{~Pb}$ contained in the sample solution.

The samples were re-plated and the ${ }^{210} \mathrm{Po}$ activities were determined. The second deposition provided information about the ${ }^{210} \mathrm{~Pb}$ content of the samples and thus indicated the extent to which the initial ${ }^{210} \mathrm{Po}$ was supported by its grandparent species.

Well known Bateman equations were used to obtain ${ }^{210} \mathrm{~Pb}$ activity from measured ${ }^{210} \mathrm{Po}$ activity.

Lower limit of detection (LLD) was calculated using the Currie definition (Currie, 1968). The concentration of ${ }^{210} \mathrm{Po}$ in a small number of samples was below the detection limit, but most of the ${ }^{210}$ Po levels were within detection limits $(0.0003 \mathrm{~Bq})$. Counting period was adjusted to obtain 
Table $1{ }^{210} \mathrm{Po}$ and ${ }^{210} \mathrm{~Pb}$ concentrations in sediment from different regions of the Aegean Sea

\begin{tabular}{llll}
\hline Area & ${ }^{210} \mathrm{Po}\left(\mathrm{Bq} \mathrm{kg}^{-1}\right.$ dry wt. $)$ & ${ }^{210} \mathrm{~Pb}\left(\mathrm{~Bq} \mathrm{~kg}^{-1}\right.$ dry wt. $)$ & References \\
\hline Milos Island & $60 \pm 8-100 \pm 10$ & $10 \pm 2-20 \pm 2$ & Boisson et al. (2001) \\
Gökova Bay & - & $50 \pm 4-113 \pm 8$ & Ugur and Yener (2001) \\
Izmir Bay & $43 \pm 6-132 \pm 12$ & $27 \pm 5-91 \pm 9$ & Saçan et al. (2010) \\
Milos Island & $20 \pm 2-166 \pm 8$ & $14 \pm 3-107 \pm 3$ & Uğur et al. (2003) \\
Izmir Bay & $36 \pm 2-109 \pm 8$ & $18 \pm 3-59 \pm 4$ & This study \\
Didim & $24 \pm 5-126 \pm 6$ & $24 \pm 2-36 \pm 4$ & This study \\
\hline
\end{tabular}

relative standard error of approximately $5 \%$. Final activity calculations were attained to include the appropriate corrections for blanks and also for collection date. Recovery was obtained to vary between 70 and $81 \%$ for samples.

\section{Metal analysis}

One gram of the sediment sample was dissolved in concentrated nitric acid in a Teflon beaker and small amount of hydrofluoric acid was added. $5 \mathrm{~mL}$ of concentrated $\mathrm{H}_{2} \mathrm{SO}_{4}$ was added on the sample and the beaker placed on the hot plate at $70-80{ }^{\circ} \mathrm{C}$. After, a small amount of the concentrated $\mathrm{HNO}_{3}$ was added very slowly and continued heating at $120{ }^{\circ} \mathrm{C}$. When the sample solution became liquid, hydrogen peroxide was added and heating continued at the same temperature for $30 \mathrm{~min}$. The hydrogen peroxide was added until the sample became clear. After that, the sample was diluted to $100 \mathrm{~mL}$ with $2 \% \mathrm{HNO}_{3}$ in a volumetric flask (Topçuoğlu et al. 2002). Trace metal levels (Mn, Fe, $\mathrm{Cr}, \mathrm{Ni}, \mathrm{Zn}, \mathrm{Cu}, \mathrm{Cd}$ and $\mathrm{Pb}$ ) were determined by a PerkinElmer inductively coupled plasma-optical emission spectrometry (ICP-OES).

\section{Results and discussion}

The activity concentrations of ${ }^{210} \mathrm{Po}$ and ${ }^{210} \mathrm{~Pb}$ were determined within the range of $24 \pm 5$ to $126 \pm 6 \mathrm{~Bq} \mathrm{~kg}^{-1}$ dry wt. with an average value of $67 \pm 2 \mathrm{~Bq} \mathrm{~kg}^{-1}$ and $18 \pm 3$ to $59 \pm 4 \mathrm{~Bq} \mathrm{~kg}^{-1}$ dry wt. with an average value of $37 \pm 1 \mathrm{~Bq} \mathrm{~kg}^{-1}$, respectively. These values were comparable with those given in literature for sediments from different region in Aegean Sea as shown in Table 1. The activity of ${ }^{210} \mathrm{Po}$ and ${ }^{210} \mathrm{~Pb}$ in marine sediment samples of Didim and Izmir Bay is also shown in Figs. 2 and 3. The activity of ${ }^{210} \mathrm{Po}$ and ${ }^{210} \mathrm{~Pb}$ in sediment samples was found to be high in ${ }^{210} \mathrm{Po}$ compared to ${ }^{210} \mathrm{~Pb}$. The highest ${ }^{210} \mathrm{Po}$ concentrations were measured in Didim $\left(126 \mathrm{~Bq} \mathrm{~kg}^{-1}\right)$ sediments. The possible source for enhanced ${ }^{210} \mathrm{Po}$, especially in Didim, is the discharge of Büyük Menderes river. The river flows into Didim station after carrying fertilized agricultural soil.

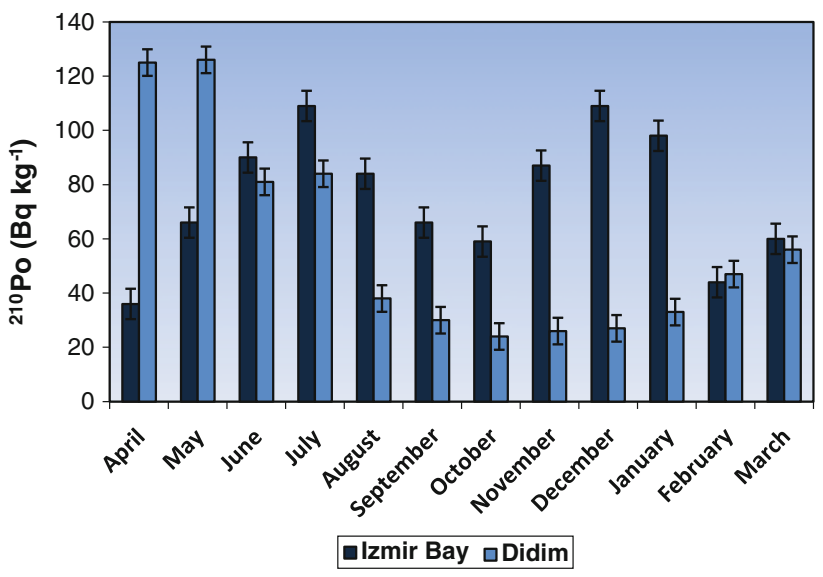

Fig. 2 Activity concentrations of ${ }^{210} \mathrm{Po}\left(\mathrm{Bq} \mathrm{kg}^{-1}\right.$ dry wt.) in sediments of the Izmir Bay and Didim

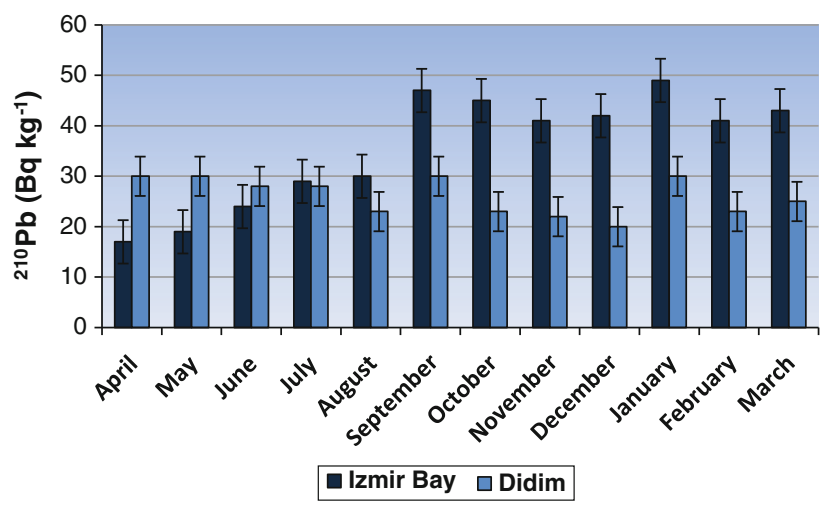

Fig. 3 Activity concentrations of ${ }^{210} \mathrm{~Pb} \quad\left(\mathrm{~Bq} \mathrm{~kg}^{-1}\right.$ dry wt.) in sediments of the Izmir Bay and Didim

Likewise, Saçan et al. (2010) studied ${ }^{210} \mathrm{Po}$ and ${ }^{210} \mathrm{~Pb}$ concentrations in sediment samples from the Izmir Bay (Aegean Sea), and determined that the highest ${ }^{210} \mathrm{Po}$ activities were observed in winter and summer periods. They pointed out that an increase in ${ }^{210} \mathrm{Po}$ concentrations has been observed in Izmir Bay, probably due to inputs from the Melez stream which is polluted by untreated wastewaters such as industrial, domestic and agricultural sources. 
The ${ }^{210} \mathrm{Po} /{ }^{210} \mathrm{~Pb}$ activity ratio is also investigated in the present study. The ${ }^{210} \mathrm{Po} /{ }^{210} \mathrm{~Pb}$ ratio for Didim and Izmir Bay stations is found to be ranged from 0.83 to 4.03 , and from 0.88 to 3.21 , respectively. Also, the mean ${ }^{210} \mathrm{Po} /{ }^{210} \mathrm{~Pb}$ ratio for Didim and Izmir Bay is determined to be 1.86 and 1.96, respectively. In general, the ${ }^{210} \mathrm{Po} /{ }^{210} \mathrm{~Pb}$ activity ratios are higher than unity in the measured samples. In study, the highest ${ }^{210} \mathrm{Po} /{ }^{210} \mathrm{~Pb}$ activity ratios were obtained in Didim for April.

The range of trace metal concentrations ( $\mu \mathrm{g} \mathrm{g}^{-1}$ dry wt.) in the Izmir Bay and Didim sediments (respectively) were: Cr 9-65 and 9-22, Cu 9-38 and 3-9, Fe 4709-18470 and 1271-11405, Mn 76-542 and 42-371, Ni 5-33 and 3-18, $\mathrm{Pb}$ 0-16 and BDL, Zn 17-85 and 3-30 $\mu \mathrm{g} \mathrm{g}^{-1}$.

Table 2 Minimum and maximum values of metals in sediments during 2006- 2007 from Izmir Bay and Didim ( $\mu \mathrm{g} \mathrm{g}^{-1}$ dry wt.)

\begin{tabular}{clllll}
\hline & Mean & Standard deviation & Min. & Median & Max. \\
\hline Didim & & & & & \\
$\mathrm{Cd}$ & $\mathrm{BDL}$ & $\mathrm{BDL}$ & $\mathrm{BDL}$ & $\mathrm{BDL}$ & $\mathrm{BDL}$ \\
$\mathrm{Cr}$ & 17.42 & 3.92 & 9.00 & 17.50 & 22.00 \\
$\mathrm{Cu}$ & 5.00 & 1.81 & 3.00 & 5.00 & 9.00 \\
$\mathrm{Fe}$ & 4496 & 3227 & 1271 & 4050 & 11405 \\
$\mathrm{Mn}$ & 149.80 & 105.20 & 42.00 & 122.00 & 371.00 \\
$\mathrm{Ni}$ & 6.75 & 4.59 & 3.00 & 4.50 & 18.00 \\
$\mathrm{~Pb}$ & $\mathrm{BDL}$ & $\mathrm{BDL}$ & $\mathrm{BDL}$ & $\mathrm{BDL}$ & $\mathrm{BDL}$ \\
$\mathrm{Zn}$ & 14.00 & 7.93 & 3.00 & 13.00 & 30.00 \\
$\mathrm{Izmir}$ & $\mathrm{Bay}$ & & & & \\
$\mathrm{Cd}$ & $\mathrm{BDL}$ & $\mathrm{BDL}$ & $\mathrm{BDL}$ & $\mathrm{BDL}$ & $\mathrm{BDL}$ \\
$\mathrm{Cr}$ & 25.92 & 17.22 & 9.00 & 20.00 & 65.00 \\
$\mathrm{Cu}$ & 23.50 & 11.52 & 9.00 & 25.50 & 38.00 \\
$\mathrm{Fe}$ & 9491 & 3941 & 4709 & 8881 & 18470 \\
$\mathrm{Mn}$ & 224.2 & 174.8 & 76.00 & 121.00 & 542.00 \\
$\mathrm{Ni}$ & 13.33 & 8.22 & 5.00 & 10.50 & 33.00 \\
$\mathrm{~Pb}$ & 7.08 & 6.68 & 0.00 & 8.00 & 16.00 \\
$\mathrm{Zn}$ & 45.83 & 26.44 & 17.00 & 50.50 & 85.00 \\
\hline $\mathrm{BDL}$ & & & & &
\end{tabular}

$B D L$ below detection limit
Minimum and maximum concentrations of trace metals $(\mathrm{Cd}, \mathrm{Cr}, \mathrm{Cu}, \mathrm{Fe}, \mathrm{Mn}, \mathrm{Ni}, \mathrm{Pb}$ and $\mathrm{Zn}$ ) determined in the sediments are presented in Table 2. The highest concentrations of metals were found in the Izmir Bay which is intensely industrialized (mainly iron, paper and pulp factories, antifouling paints, chlorine-alkali plants, chemical industries, textile industries, metal processing, timber processing, cement factories, tanneries, oil, soap and a very busy harbor) compared to Didim.

In the past, various studies were conducted to determine the trace metals in the sediments of Izmir Bay.

Metal concentrations ( $\mu \mathrm{g} \mathrm{g}^{-1}$ dry wt.) in sediments of Didim and Izmir Bay were compared to other studies in sediments from different regions of the world (Table 3). Comparison of data set revelated that observed trace metal levels in the Didim and Izmir Bay were generally lower than other regions. On the other hand, the levels of metals in this study were higher than Egypt. Different extraction procedures were used in the previous studies and this may have contributed to the differences (Güven and Akınc1 2008).

\section{Conclusions}

The following conclusions can be derived:

1. The activity concentrations of ${ }^{210} \mathrm{Po}$ and ${ }^{210} \mathrm{~Pb}$ were determined in the surface marine sediments in Izmir Bay and Didim (Aegean Sea).

2. The activity concentrations of ${ }^{210} \mathrm{Po}$ were determined within the range of $24 \pm 5$ to $126 \pm 6 \mathrm{~Bq} \mathrm{~kg}^{-1}$ dry wt.

3. The activity concentrations of ${ }^{210} \mathrm{~Pb}$ were determined within the range of $18 \pm 3$ to $59 \pm 4 \mathrm{~Bq} \mathrm{k}^{\mathrm{g}-1}$ dry wt.

4. The highest ${ }^{210}$ Po concentration was observed at the Didim station.

5. ${ }^{210} \mathrm{~Pb}$ activity concentrations in most of the sediment samples were lower than ${ }^{210} \mathrm{Po}$, and usually ${ }^{210} \mathrm{Po} /{ }^{210} \mathrm{~Pb}$ activity ratios are much higher for natural levels.

Table 3 The metal concentrations in sediments ( $\mu \mathrm{g} \mathrm{g}^{-1}$ dry wt.) from Izmir Bay and Didim and different regions of the world

\begin{tabular}{lllllll}
\hline Area & $\mathrm{Pb}$ & $\mathrm{Cr}$ & $\mathrm{Cu}$ & $\mathrm{Zn}$ & $\mathrm{Mn}$ & References \\
\hline Homa Lagoon (Turkey) & $2.43-17$ & $84-129$ & $10-26$ & $46-92$ & $410-729$ & Uluturhan et al. (2011) \\
Izmir Bay (Turkey) & $3.1-119$ & $19-316$ & $2.2-109$ & $14-412$ & $128-942$ & Küçüksegin et al. (2011) \\
Berre (France) & $18-82$ & $38-428$ & $11-48$ & $50-151$ & - & Accornero et al. (2008) \\
Izmit Bay (Turkey) & $55.2-172$ & $38.9-112.4$ & $24.5-102.4$ & $440-1900$ & - & Pekey (2006) \\
Venice (Italy) & $21-929$ & - & - & $101-8295$ & - & Bellucci et al. (2002) \\
Bardawil (Egypt) & $0-78$ & $1.4-24$ & $0.78-4.4$ & $3.9-29$ & $2.7-25$ & Taher (2001) \\
Saros Gulf (Turkey) & $2-80$ & - & $6-44$ & $23-154$ & $114-1740$ & Sarı and Cağatay (2001) \\
Aegean Sea (Turkey) & $0-16$ & $9-65$ & $3-38$ & $3-85$ & $42-542$ & This study \\
\hline
\end{tabular}


6. The overall order of the metal concentrations found in sediments in our study was: $\mathrm{Fe}>\mathrm{Mn}>\mathrm{Zn}>\mathrm{Cr}>-$ $\mathrm{Cu}>\mathrm{Ni}>\mathrm{Pb}>\mathrm{Cd}$. Our results show that the distribution of metals in the surface sediment is variable.

Open Access This article is distributed under the terms of the Creative Commons Attribution License which permits any use, distribution, and reproduction in any medium, provided the original author(s) and the source are credited.

\section{References}

Accornero A, Gnerre R, Manfra L (2008) Sediment concentrations of trace metals in the Berre Lagoon (France): an assessment of contamination. Arch. Environ. Con. Tox. 54:372-385

Bellucci LG, Frignani M, Paolucci D, Ravanelli M (2002) Distribution of heavy metals in sediments of the Venice Lagoon: the role of the industrial area. Sci Total Environ 295:35-49

Boisson F, Miquel J-C, Cotret O, Fowler SW (2001) ${ }^{210} \mathrm{Po}$ and ${ }^{210} \mathrm{~Pb}$ cycling in a hydrothermal vent zone in the coastal Aegean Sea. Sci Total Environ 281(1-3):111-119

Flynn WW (1968) The determination of low levels of polonium-210 in environmental materials. Anal Chim Acta 43:221-227

Küçüksegin F, Kontaş A, Uluturhan E (2011) Evaluations of heavy metal pollution in sediment and Mullus barbatus from the Izmir Bay (Eastern Aegean) during 1997-2009. Mar Pollut Bull 62:1562-1571

Güven DE, Akıncı G (2008) Heavy metals partitioning in the sediments of Izmir Inner Bay. J Environ Sci 20:413-418

Pekey H (2006) Heavy metal pollution assessment in sediments of the Izmit Bay. Turk Environ Monit Assess 123:219-231
Saçan S, Uğur A, Sunlu U, Büyükışık B, Aksu M, Sunlu FS (2010) The ${ }^{210} \mathrm{Po}$ and ${ }^{210} \mathrm{~Pb}$ levels in surface sediment samples in the Izmir Bay (Aegean Sea-Turkey). Environ Monit Assess 161:575-582

Sarı E, Cağatay MN (2001) Distributions of heavy metals in the surface sediments of Gulf of Saros, NE Aegean Sea. Environ Inter 26:169-173

Sill CW, Olsen DG (1970) Sources and Prevention of recoil contamination of solid-state alpha detectors. Anal Chem 42: 1596-1607

Stepnowski P, Skwarzec B (2000) Tissue and subcellular distributions of Po-210 in the crustacean Saduria entomon inhabiting the southern Baltic Sea. J Environ Radioactiv 49:195-199

Taher AG (2001) Geochemistry of recent marine sediments in the Bardawil lagoon, northern Sinai. Egypt. Hydrobiol. 457:5-16

Topçuoğlu S, Kırbaşoğlu Ç, Güngör N (2002) Heavy metals in organisms and sediments from Turkish Coast of the Black Sea, 1997-1998. Environ Int 27:521-526

Uğur (Tanbay) A, Yener G (2001) Accumulation rates and sediment deposition in the Gökova Bay in Aegean Sea Turkish Coast. Appl Radiat Isot 55:581-588

Uğur A, Miquel JC, Fowler SW, Appleby P (2003) Radiometric dating of sediment cores from a hydrothermal vent zone off Milos Island in the Aegean Sea. Sci Total Environ 307:203-214

Uluturhan E, Kontaş A, Can E (2011) Sediment concentrations of heavy metals in the Homa Lagoon (Eastern Aegean Sea): assessment of contamination and ecological risks. Mar Pollut Bull 62:1989-1997

Vreček P, Benedik L, Pihlar B (2004) Determination of $210 \mathrm{~Pb}$ and 210Po in sediment and soil leachates and in biological materials using a Sr-resin column and evaluation of column. Appl Radiat Isot 60(5):717-723 